\title{
Fiscal policy benefits and green recovery of firms: an experimental exploration of Chinese listed firms in post-Covid-19
}

\author{
Dongyang Zhang ${ }^{1}[0$
}

Received: 26 May 2021 / Accepted: 21 August 2021

(C) The Author(s), under exclusive licence to Springer Science+Business Media, LLC, part of Springer Nature 2021

\begin{abstract}
In the wake of the COVID-19 pandemic, fiscal policy is an important tool to facilitate green recovery of the economy. This paper uses the low-energy-intensive incentive support policy implemented by the Chinese government as a trial and explores the impact of fiscal policy on the green recovery of firms. Using Chinese listedfirm data from 2019Q1 to 2021Q1, we use the difference-in-differences method to estimate policy effects, leading to several findings. First, our fundamental results show that the government's low-energy-intensive support policy can significantly improve low-energy-intensive firm performance more than that of high-energyconsuming firms, with respect to return on assets, return on equity and Tobin's Q. Second, regarding the mechanisms involved, our estimation results indicate that the low-energy-intensive support policy works by alleviating financial constraints to improve firm performance. Third, our empirical findings indicate that low-energyintensive support policy can increase current ratio, liquidity and cash flow, resulting in improved firm financial resources. Finally, the fiscal support policy reduces management and financial costs, thus improving firm performance. Our findings recommend adoption of well-designed fiscal policies in regions where green economic recovery is needed.
\end{abstract}

Keywords Green recovery · Fiscal policy $\cdot$ Financial constraints $\cdot$ Firm performance

\section{Introduction}

Since the enactment of sustainable development growth goals and the Paris Climate Agreement signed by world leaders, several economies have attempted to reduce carbon emissions (Zhang and Vigne 2021a, b). However, several developed

Dongyang Zhang

zhangdongyang@cueb.edu.cn

1 School of Economics, Capital University of Economics and Business, Beijing, China 
and developing economies still follow pro-coal energy policies (e.g., Dabla-Norris et al. 2019; Taghizadeh-Hesary and Yoshino 2019; Yoshino et al. 2021; Zakari et al. 2021 As a result, the global environmental crisis shows every sign of worsening, and global carbon emissions are increasing. The International Energy Agency (IEA, 2020) provides data regarding energy efficiency and renewable energy investment separately. Figure 1 shows trends in energy efficiency and renewable energy investment, showing a significant decline after 2020. The IEA estimates that ongoing investment in renewable energy activities may fall $10 \%$ due to the shock and economic recessions caused by the COVID-19 pandemic. The extra $\mathrm{CO}_{2}$ generated by new coal-fired power plants in some nations could more than wipe out any reductions in emissions made by other nations. This could threaten the expansion of green energy needed to meet climate and clean air goals and threaten green development (Sachs et al. 2019). Unlike sustainable development, which considers all aspects of development, green recovery of the economy focuses on the environment. The term "green recovery of the economy" is backed by a logical theoretical concept that considers development that minimizes the negative impact on the environment. It is not a political concept.

In the wake of the COVID-19 pandemic, economic downturns have resulted in plummeting oil prices due to low demand and oversupply, leading to stiff competition for renewables. Further, to stimulate economic growth, many governments rolled back environmental regulations and taxes and increased fossil-fuel intensive infrastructure and electricity. This endangers the achievements of the Paris Agreement on Climate Change and several sustainable development goals. Public budget deficits increased significantly due to increased medical costs to cope with COVID-19 and due to a decline in tax revenues caused by slower economic growth.

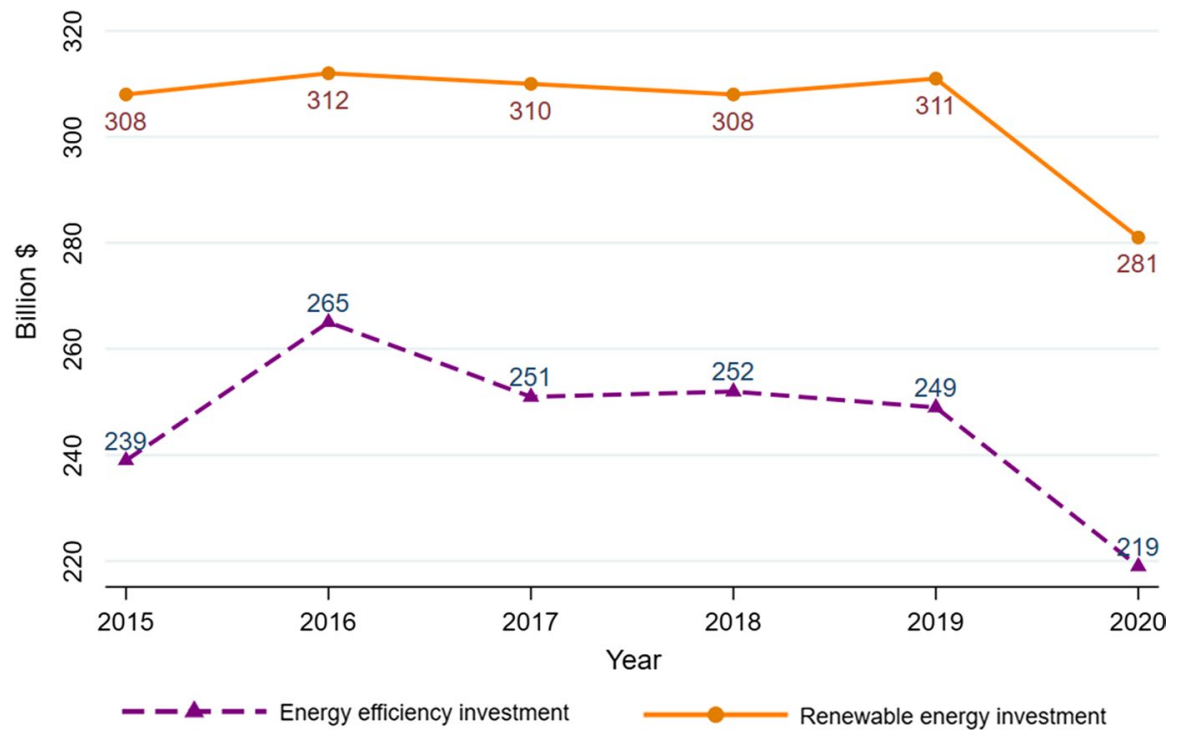

Fig. 1 Energy efficiency and renewable energy investment ( Source: International Energy Agency) 
Governments are now more keen to bring private sector financing into green energy deployment to address the world's environmental issues. To attract private sector investment into green energy projects, their rate of return has to increase (Yoshino et al. 2021). At the same time, a green-centered taxation system for polluting gases would be more effective if imposed globally.

As restrictions ease and economies reopen, governments are beginning to unveil their economic recovery plans. However, there is a lack of motivation to strengthen the green agenda in the recovery plans. This is because the recovery outlook seems to follow the "growth first and green it when possible" approach of existing development plans. Therefore, green recovery after COVID-19 is key to reducing $\mathrm{CO}_{2}$ and other pollution globally. Against this backdrop, the practicability of green growth as the dominant strategy in tackling climate change, especially within a shortening time window, needs urgent rethinking (Sembiring 2020).

Fiscal policy plays an essential role in assuring sustainable use of resources and protecting the environment (Zhang 2019, 2021). This applies to both sides of government budgets. On the revenue side, carbon taxation adjusted with green efforts and green floating rate bonds are two essential tools whose importance is increasing. Various fiscal measures could help green-specific priority sectors. Green-adjusted taxes on polluting gases can help generate revenue for environmental purposes and redirect the flow of investment from brown to green and low-carbon sectors by introducing green floating rate bonds. Therefore, in the post-Covid-19 era, governments should take responsibility for supporting green and renewable energy projects to keep up the pace of investment to achieve a green recovery and fulfill the Paris Agreement on Climate Change. Since the beginning of 2021, China's National Development and Reform Commission has issued fiscal support and energy consumption price reductions, such as electricity price reductions, for low-energy-intensive firms (hereafter, "fiscal support policy"), which aims to assist firms suffering under the Covid-19 pandemic and encourage them to upgrade to low-energy-intensive operations.

The main objective of the present study is to demonstrate that well-designed fiscal policy will be costly for high energy-consuming and polluting firms, such as those that rely on coal, are electricity intensive, or that emit $\mathrm{CO}_{2}, \mathrm{SO}_{2}, \mathrm{NOx}$. This may force investors and corporate managers to focus on return versus risk after implementation of supportive fiscal policies.

As an identification strategy, the difference-in-differences (DID) estimator is used to better identify the causal effect of green fiscal support on low-energy-intensive firm performance. By accessing quarterly data of Chinese listed firms from Q1 2019 to Q1 2021, we examine whether low-energy-intensive fiscal support can help lead to a green economy. We estimate how the effects of low-energy-intensive fiscal support on firm performance differ between low-energy-intensive and highenergy-intensive firms. This leads to several findings. First, our fundamental results show that low-energy-intensive fiscal support policy can significantly improve low-energy-intensive firms' performance over that of high-energy-intensive firms, including with respect to ROA (Return over Assets), ROE (Return over Equity) and Tobin's Q. Second, our estimation results indicate that a low-energy-intensive fiscal support policy works through alleviating financial constraints, leading to improved 
firm performance. Third, our empirical findings indicate that fiscal support policy can increase current ratio, liquidity and cash flow, resulting in improved firm financial resources. Finally, fiscal support policy reduces management and financial costs; thus, it can improve firm performance as well.

This paper makes the following contributions to the literature. The first relates to theoretical analysis, which incorporates low-energy-intensive fiscal support policy as an experimental test and investigates the impact of fiscal policy on recovery based on green economic growth following the COVID-19 pandemic. We further provide evidence that shows that fiscal policy can facilitate economic growth (Bloom et al. 2002; Wu et al. 2012) and contribute to green growth. Second, we identify the direct mechanisms through which low-energy-intensive fiscal support policy improves green production firms' performance. Although prior studies show that effective policy design can help firm performance (Giombini et al. 2018; Alm et al. 2019), there is little discussion on the mechanisms of recovery and green growth. We provide detailed evidence that green production firms' financial constraints are alleviated by the low-energy-intensive fiscal support policy, and internal financings improve. Our findings enrich the literature on the relationship between financial constraints and government support (Howell 2016; Zhang 2021). Third, we extend the limited empirical findings on economic recovery in the aftermath of the COVID19 pandemic. This paper adds a new finding that shows that effective fiscal policy can help alleviate the financial constraints caused by uncertainty and facilitate green growth. Our results may serve as a starting point for further research in this regard.

This paper proceeds as follows. Section 2 links fiscal policy, financial constraints and firm performance. Section 3 introduces our data and variable designs. Section 4 outlines the procedure to estimate our identifications. Sections 5 and 6 present our results, and Sect. 7 sets forth our conclusions.

\section{Literature review and hypothesis development}

Government subsidies and tax incentives are important tools of macroeconomic control and adjustment and have significant influence on capital markets and firm financial decisions. Government subsidies aim to support industry development and upgrading (Wang and Chen 2005) and to stimulate R\&D activity (Chen and Zhu 2008; Zhang et al. 2020). Generally, government subsidies have political purposes; government subsidies are intended to provide public services and increase employment (Tang and Luo 2007). Additionally, government subsidies are designed with market-based purposes, including refinancing or avoiding delisting (Chen and Zhu 2009), and government subsidies can cause financing to deviate from the purpose of maximizing value by adjusting the market mechanism of allocation of capital. Prior evidence has shown that efficient government subsidy improves social welfare, R\&D efficiency and export behavior (Faccio et al. 2006; Dever 2010; Pan et al. 2009).

The impact of government tax incentives on firm performance has been widely investigated. Klassen et al. (2004) conclude that different tax credit and incentive mechanisms can help reduce firm financial constraints, thereby increasing investment in R\&D projects. These authors also find that the efficiency of the tax credit 
mechanism differs among countries. China's value-added tax (VAT) reform is shown to reduce firm tax burdens, alleviate financial constraints and spur sales of new products and processes (Howell 2016).

In China, different types of fiscal policy target different purposes and levels of efficiency. To a certain extent, a green incentive tax support policy can be viewed as capital invested in firms that improves decision-making and supervision efficiency. Therefore, the green incentive tax policy focuses on tax reduction for lowenergy-intensive firms and aims to overcome the financial shocks caused by the COVID-19 pandemic. This facilitates the sustainable growth of low-energy-intensive firms. Thus, we propose our fundamental hypothesis as follows:

Hypothesis 1 Green incentive tax policy can improve performance in low-energyintensive firms.

The prevailing perspective on the impact of fiscal policy is that firms internally generate funds via fiscal support policies, such as government subsidies and incentive taxes, which results in alleviating financial constraints and improving firm performance. Evidence shows that government subsidy improves the firm financing environment, allowing firms previously affected by financial constraints to better invest in value-enhancing projects and innovation, thus helping firms survive fierce competition (Zhang et al. 2020). Other research indicates that indirect subsidy programs have an extensive and strong role in improving firm performance, especially through alleviating financial constraints and facilitating innovation outcomes, whereas direct subsidy programs have weak effects (Nishimura and Okamuro 2011). However, not all government subsidy programs have a positive effect on firm performance. Bu et al. (2017) find that a non-specified subsidy reduces investment efficiency and results in rent-seeking activities, and a subsidy with a definite purpose has better efficiency than a subsidy without a definite purpose.

Regarding the impact of incentive tax policy, a growing literature shows that firms use tax avoidance as an important source of internal financing in response to greater financial constraints. Financially constrained firms generally employ tax planning strategies such as reducing current reported taxable income or increasing tax credits, decreasing cash taxes paid and increasing internal cash reserves (Edwards et al. 2016). However, Bayar et al. (2018) indicate a potentially important effect of managerial incentives and corporate governance on the endogenous relation between corporate tax avoidance and financial constraints. Only when firms have strong governance mechanisms can tax avoidance help firms to relax their financial constraints to a certain extent (Bayar et al. 2018). Meanwhile, firms are found to use tax evasion strategies to address issues created by financial constraints (Alm et al. 2019).

Therefore, we propose the following hypothesis:

Hypothesis 2 Green incentive tax policy can improve low-energy-intensive firm performance through alleviation of financial constraints. 
In particular, the impact of tax incentives on firm performance is moderated by management quality. When corporate managers are aware that incentive tax administration plays a positive role in their transactions and firm upgrading, high-quality management can significantly reduce associated costs by allocating financial resources efficiently (Firth et al. 2006). The efficiency of tax support policy can be strengthened by connected managers, and effective tax administration reduces tax compliance costs and increases productivity (Dabla-Norris et al. 2019), especially for private firms in China (Wu et al. 2012). Thus, for low-energy-intensive firms, taxes saved through a green incentive tax can be efficiently managed and reduce firm costs, resulting in improved firm performance. Thus, we propose the following hypothesis:

Hypothesis 3 Green incentive tax policy can improve low-energy-intensive firm performance through moderating financial costs.

In accordance with the previous discussion, this paper adds instrumental insights to the literature. The research design can support the role of well-designed fiscal policy in affecting the green economy movement (Mohsin et al. 2021). This paper examines the impact of fiscal policy not only on facilitating economic growth (Bloom et al. 2002; Wu et al. 2012), but on recovery through green economic growth following the COVID-19 pandemic through alleviating uncertainty in lowenergy-intensive firms. In addition, regardless of consistent evidence proving the economic recovery concept, this paper proposes to minimize market failure caused by COVID-19 through increased fiscal support via empirical evidence regarding the presence of a technical effect (Zhang et al. 2021). According to our hypothesis discussed above, government policy can foster green economic development through efficient targeted fiscal policy, leading low-energy-intensive firms and industries to achieve sustainable economic development. The mechanism of transformation is demonstrated in this paper. Hence, for firms to benefit from fiscal policy targeting green economic recovery, it is vital to uncover the underlying mechanisms. Our hypothesis 3 addresses financial constraint alleviation and financial cost reduction to help achieve the green recovery target.

\section{Data and summary statistics}

\subsection{Data}

Our database pulls information on listed Chinese firms from the China Stock Market \& Accounting Research Database for the period 2019Q1-2021Q1. This database has several crucial features. First, it is comprehensive, and its large samples decrease the probability of biased estimation. Second, our database contains broad variables, including firm characteristics and financial variables. Thus, we can test more mechanisms in our models and better overcome the omitted variables problem. Third, we use quarterly data that include two complete years in the same business cycle. 


\subsection{Descriptive statistics}

Table 1 provides summary statistics of the main variables. We distinguish the control group from the treatment group by whether a firm is subsidized, and we measure firm performance by ROA, ROE and Tobin's Q (Wu et al. 2012). ROA is a measure of net profit generated per unit of assets, with mean of $2.2 \%$. ROE measures return on shareholder equity and firm efficiency in using its own capital to obtain net income, with mean of $4.5 \%$. Tobin's $\mathrm{Q}$ is a ratio of the firm's market value to its replacement value, and the average value is 2.406 . In addition, there is a significant difference between the means of the two groups of firms, and green tax-supported firms show better performance. We use the WW index (Whited and $\mathrm{Wu} 2006$ ) and $\mathrm{KZ}$ index (Kaplan and Zingales 1997) to measure firm financial constraints. The $\mathrm{KZ}$ index is 1.168 versus 1.184 , and the $\mathrm{WW}$ index is 6.576 versus 6.666 between treated and control groups. The treatment group performs better for these two variables. Compared with these indicators the control group, which illustrates that green tax subsidized firms are less financially constrained. Current Ratio is the same variable as liquidity, reflecting the flexibility of a firm's capital. Table 1 shows that the treatment group has high liquidity in financing firms. Moreover, the financial cost, including management cost, financial cost, performs better for the treated group, and R\&D expenditure has a high value for treated group as well.

Table 1 Summary statistics

\begin{tabular}{lrrrrrrrr}
\hline Variable & Obs & Mean & SD & \multicolumn{1}{l}{ Min } & Max & Control & Treat & Diff \\
\hline Post & 45,236 & 0.345 & 0.475 & 0.000 & 1.000 & -.339 & 0.347 & -0.008 \\
Treat & 45,236 & 0.705 & 0.456 & 0.000 & 1.000 & 0.000 & 1.000 & -1.000 \\
ROA & 22,872 & 0.022 & 0.044 & -0.187 & 0.154 & 0.019 & 0.028 & $-0.009 * * *$ \\
ROE & 22,782 & 0.045 & 0.099 & -0.500 & 0.346 & 0.041 & 0.054 & $-0.013 * * *$ \\
Tobin's Q & 22,770 & 2.406 & 2.420 & 0.544 & 48.330 & 2.193 & 2.499 & $-0.306^{* * *}$ \\
Sales growth & 38,548 & 0.508 & 0.821 & -0.921 & 3.299 & 0.466 & 0.526 & $-0.060^{* * *}$ \\
Firm size & 42,498 & 22.379 & 1.469 & 19.713 & 27.367 & 22.347 & 22.392 & $-0.045^{* * *}$ \\
Firm age & 25,533 & 2.130 & 0.904 & 0.000 & 3.401 & 2.223 & 2.089 & $0.135 * * *$ \\
WW index & 15,459 & 1.173 & 0.110 & 0.845 & 1.338 & 1.184 & 1.168 & $0.016^{* * *}$ \\
KZ index & 14,672 & 6.605 & 1.042 & 4.021 & 9.089 & 6.666 & 6.576 & $0.090^{* * *}$ \\
Current ratio & 22,359 & 2.508 & 2.553 & 0.317 & 16.469 & 2.489 & 2.516 & -0.028 \\
Liquidity & 22,363 & 0.815 & 0.175 & 0.262 & 1.000 & 0.793 & 0.825 & $-0.032^{* * *}$ \\
Short-term debt & 22,277 & 0.339 & 0.180 & 0.040 & 0.869 & 0.307 & 0.353 & $-0.046 * * *$ \\
Long-term debt & 15,527 & 0.096 & 0.098 & 0.000 & 0.457 & 0.098 & 0.095 & $0.003 *$ \\
Management cost & 22,346 & 0.097 & 0.132 & 0.007 & 1.019 & 0.077 & 0.106 & $-0.029 * * *$ \\
Financial cost & 22,342 & 0.027 & 0.075 & -0.076 & 0.526 & 0.023 & 0.028 & $-0.005^{* * *}$ \\
R\&D Expenditure & 19,740 & 0.049 & 0.056 & 0.000 & 0.338 & 0.032 & 0.057 & $-0.025^{* * *}$ \\
Confirmed Cases & 12,636 & 2.548 & 1.640 & 0.000 & 7.287 & 2.312 & 2.639 & $-0.327 * * *$ \\
\hline & & & & & & & & \\
\hline
\end{tabular}




\section{Theoretical discussion and econometric specifications}

\subsection{Theoretical discussion}

The need for further and rapid action to limit the increase in uncertainty in the post-COVID-19 era, as well as the need to control the resulting high transition risks in the green recovery, along with avoiding physical and liability risks in terms of firm financial status, has forced the discussion with respect to the role that government could play in the transition to a green economy (Sartzetakis 2020; Shaikh 2021). Since the green production and green recovery-oriented transition will carry high costs, these transition costs will diminish firms' profit maximization targets. In general, government fiscal policy has political purposes, including supporting industry development and upgrading (Wang and Chen 2005; Aydin 2007) and stimulating R\&D activity (Chen and Zhu 2008; Zhang et al. 2020). Additionally, fiscal policy is designed to make financing deviate from the purpose of maximizing value by adjusting the market mechanism underlying allocation of capital (Chen and Zhu 2009). Hence, well-designed fiscal policy can motivate firms toward the green transition by lowering costs or providing subsidies. In addition, fiscal policy can help firms internally generate funds via fiscal support policies, such as government subsidies and incentive taxes, which result in alleviating financial constraints and improving firm performance (Zhang et al. 2020). Therefore, efficient fiscal policy can help green recovery for firms by improving their financial performance, which results in improving green technology development and thus reducing energy consumption and pollution emissions (Kim et al. 2021). We summarize our theoretical framework in Fig. 2.

\subsection{Econometric specifications}

To explore the effects of a low-energy-intensive fiscal support policy on firm performance and the mechanisms of financial intermediation, we incorporate the following DID model to estimate.

$$
\text { Performance }_{i, t}=\alpha_{0}+\beta_{1} \text { Post }_{t}+\beta_{2} \text { Treat }_{i}+\beta_{3} \text { Post }_{t} * \text { Treat }_{i}+\beta_{i} X_{i, t}+v_{j}+v_{r}+\varepsilon_{i, t}
$$

where Performance ${ }_{i, t}$ measures performance of firm $i$ in period $t$, using ROA, ROE and Tobin's $Q$ to measure this indicator; Treat $_{i}$ is a dummy variable that equals 1 if a firm is less energy-intensive and can benefit from green tax policies, and 0 otherwise; Post $t_{t}$ equals 1 if observation time is after implementation of the low-energyintensive fiscal support policy, that is, Q1 of 2020, and 0 otherwise; the effects of a low-energy-intensive fiscal support policy on firm performance are estimated using $\beta_{3} ; X_{i, t}$ are the control variables, including firm size (logarithm of total assets), sales growth and firm age; $v_{j}$ and $v_{r}$ are fixed effects, including time fixed effect and industry fixed effect, respectively, and $\varepsilon_{i, t}$ are the error terms. 


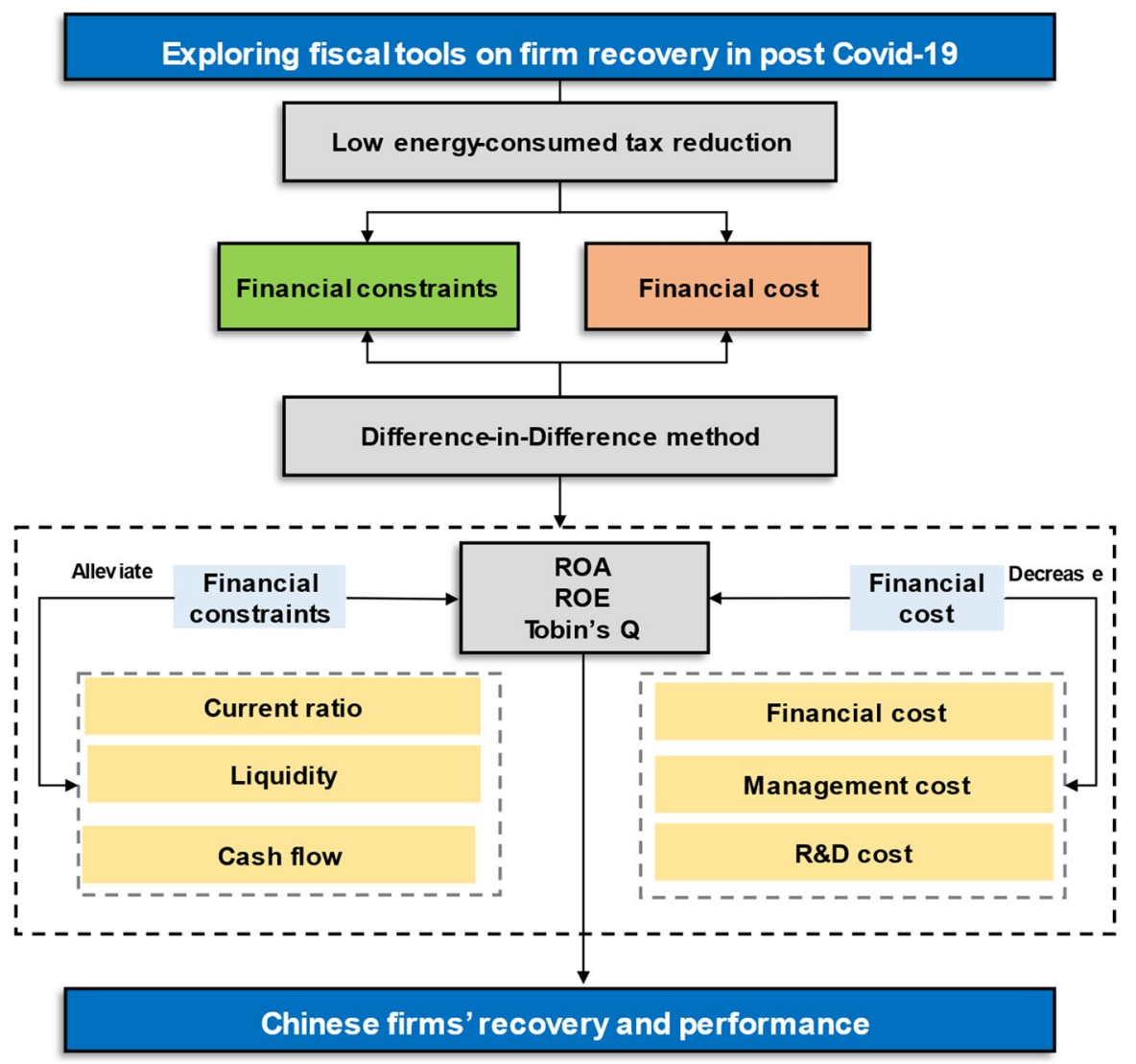

Fig. 2 Theoretical framework

In general, difference in difference is widely used to measure the policy impact, and we set our estimation model as Eq. (1).

Here, Performance ${ }_{i, t}$ represents firm performance, in terms of ROA, ROE and Tobin's Q. $\beta_{3}$ is the main interest of this paper, which captures the causal effect of supportive policy on firm performance between low and high energy-consumed firms. treat ${ }_{i}$ indicates whether or not a firm belongs to a heavily energy consumed industry (a firm in heavily energy consumed industry equals 1 and 0 otherwise), post $_{t}$ presents whether or not the policy was implemented (before policy implementation equals 0 ; after policy implementation equals 1 ).

The estimation methods can help us estimate an unbiased coefficient $\beta_{3}$.

$\left(\right.$ Performance $_{\text {treat } 11}-$ Performance $\left._{\text {treat } 21}\right)-\left(\right.$ Performance $_{\text {treat } 12}-$ Performance $\left._{\text {treat } 22}\right)$, 
Equation (2) was used interpret the impact of the policy regulations on heavily energy-consumed firms.

(Performance $_{\text {control 11 }}-$ Performance $\left._{\text {control 21 }}\right)-\left(\right.$ Performance $_{\text {control 12 }}-$ Performance $\left._{\text {control 22 }}\right)$

Meanwhile, Eq. (3) interprets the impact of the policy regulations on lightly energy-consumed firms.

Therefore, the pure effect of the policy on firm performance is estimated by $\beta_{3}$, which equals

$$
\left[\left(y_{\text {treat 11 }}-y_{\text {treat 21 }}\right)-\left(y_{\text {treat 12 }}-y_{\text {treat 22 }}\right)\right]-\left[\left(y_{\text {control 11 }}-y_{\text {control 21 }}\right)-\left(y_{\text {control 12 }}-y_{\text {control 22 }}\right)\right] \text {. }
$$

As a result, we should use the data containing both before and after the COVID19 ; therefore, we can estimate the fiscal policy can significantly improve firm performance for lowly energy-consumed firms in the post-COVID-19 era. Therefore, we choose time period of 2019Q1-2021Q1.

To better explore the mechanisms underlying alleviation of financial constraints via low-energy-intensive fiscal support policy, on the basis of the DID model in Eq. (1), we introduce a two-step estimation design to investigate the mechanism of our hypothesis 2 .

$$
\text { Performance }_{i, t}=\alpha_{0}+\beta_{1} \cdot \text { Financial constraints }_{i, t}+\beta_{i} X_{i, t}+v_{j}+v_{r}+\varepsilon_{i, t}
$$

Financial constraints ${ }_{i, t}=\alpha_{0}+\beta_{1}$ Post $_{t}+\beta_{2}$ Treat $_{i}+\beta_{3}$ Post $_{t}$ Treat $_{i}+\beta_{i} X_{i, t}+v_{j}+v_{r}+\varepsilon_{i, t}$

where financial constraints are calculated by $\mathrm{KZ}$ index or WW index, and Eq. (5) is used to identify whether firm performance is financially constrained. Once the hypothesis is proved, $\beta_{3}$ becomes our target variable to estimate the low-energyintensive fiscal support that can improve firm performance through reducing financial constraints. This can well describe the extent to which financial constraints affect firm performance, and green tax subsidy policy indirectly affects firm performance by improving the firm financial environment.

We further test whether low-energy-intensive fiscal support works by reducing firm management costs, financial costs and increasing R\&D expenditure. The estimation equation is as follows:

$$
\text { Cost }_{i, t}=\alpha_{0}+\beta_{1} \text { Post }_{t}+\beta_{2} \text { Treat }_{i}+\beta_{3} \text { Post }_{t} \text { Treat }_{i}+\beta_{i} X_{i, t}+v_{j}+v_{r}+\varepsilon_{i, t} .
$$


Table 2 Baseline regression results

\begin{tabular}{|c|c|c|c|c|c|c|}
\hline \multirow[t]{2}{*}{ Variables } & (1) & (2) & (3) & (4) & (5) & (6) \\
\hline & ROA & ROE & Tobin's Q & ROA & ROE & Tobin's Q \\
\hline \multirow[t]{2}{*}{ Post } & $0.012 * * *$ & $0.033 * * *$ & $0.209 * * *$ & $0.015 * * *$ & $0.037 * * *$ & $0.428 * * *$ \\
\hline & $(0.003)$ & $(0.006)$ & $(0.017)$ & $(0.003)$ & $(0.006)$ & $(0.021)$ \\
\hline \multirow[t]{2}{*}{ Treat } & $-0.015 * * *$ & $-0.025 * * *$ & $0.259 * * *$ & $-0.018 * * *$ & $-0.029 * * *$ & $0.124 * * *$ \\
\hline & $(0.002)$ & $(0.005)$ & $(0.051)$ & $(0.002)$ & $(0.005)$ & $(0.029)$ \\
\hline \multirow[t]{2}{*}{ Post $\times$ Treat } & $0.005 * * *$ & $0.009 * * *$ & $0.102 * * *$ & $0.006 * * *$ & $0.010 * * *$ & $0.035 * *$ \\
\hline & $(0.001)$ & $(0.003)$ & $(0.024)$ & $(0.001)$ & $(0.003)$ & $(0.013)$ \\
\hline \multirow[t]{2}{*}{ Sales growth } & & & & 0.001 & $0.007 * * *$ & 0.007 \\
\hline & & & & $(0.001)$ & $(0.002)$ & $(0.090)$ \\
\hline \multirow[t]{2}{*}{ Firm size } & & & & $0.004 * * *$ & $0.013 * * *$ & $-0.534 * * *$ \\
\hline & & & & $(0.000)$ & $(0.001)$ & $(0.016)$ \\
\hline \multirow[t]{2}{*}{ Firm age } & & & & $-0.011 * * *$ & $-0.017 * * *$ & $-0.246 * *$ \\
\hline & & & & $(0.000)$ & $(0.001)$ & $(0.099)$ \\
\hline \multirow[t]{2}{*}{ Constant } & $0.012 * * *$ & $0.065 * * *$ & $0.509 * * *$ & $-0.079 * * *$ & $-0.256^{* * *}$ & $14.823 * * *$ \\
\hline & $(0.004)$ & $(0.009)$ & $(0.103)$ & $(0.007)$ & $(0.018)$ & $(0.333)$ \\
\hline Time fixed effect & Yes & Yes & Yes & Yes & Yes & Yes \\
\hline Industry fixed effect & Yes & Yes & Yes & Yes & Yes & Yes \\
\hline Observations & 22,872 & 22,782 & 22,770 & 22,207 & 22,116 & 22,162 \\
\hline$R$-squared & 0.066 & 0.049 & 0.027 & 0.111 & 0.083 & 0.149 \\
\hline
\end{tabular}

Robust standard errors in parentheses

$* * * p<0.01 ; * * p<0.05 ; * p<0.1$

\section{Empirical results}

\subsection{Baseline results}

Using Eq. (1), we estimate our baseline results and show our findings in Table 2. ROA, ROE and Tobin's Q are used to represent firm performance, separately. Columns 1-3 show the regression result of our fundamental DID model without incorporating the control variables. We find that the coefficient of the interaction term Post ${ }^{*}$ Treat is significantly positive (at the $1 \%$ significance level), which means that the policy of low-energy-intensive fiscal support plays a positive role in improving firm performance. Columns 4-6 further present the estimation results after incorporating the control variables, including sales growth, firm size and firm age. The coefficient of Post*Treat is still positive and significant, which demonstrates that our fundamental results are reliable. With respect to our control variables, sales growth plays a positive role in improving firm 
Table 3 Fiscal policy dynamic effect results

\begin{tabular}{|c|c|c|c|}
\hline \multirow[t]{2}{*}{ Variables } & (1) & (2) & (3) \\
\hline & ROA & ROE & Tobin's Q \\
\hline \multirow[t]{2}{*}{ Post } & $-0.024 * *$ & $-0.042 * * *$ & 0.201 \\
\hline & $(0.001)$ & $(0.000)$ & $(0.061)$ \\
\hline \multirow[t]{2}{*}{ Treat } & $-0.016^{* *}$ & $-0.030 * * *$ & $0.035 * *$ \\
\hline & $(0.000)$ & $(0.000)$ & $(0.002)$ \\
\hline \multirow[t]{2}{*}{ Post $\times$ treat } & $0.012 * * *$ & $0.021 * * *$ & $0.044 *$ \\
\hline & $(0.000)$ & $(0.000)$ & $(0.004)$ \\
\hline \multirow[t]{2}{*}{ Post $\times$ treat $_{2}$} & $0.003 * *$ & $-0.009 * * *$ & $0.034 *$ \\
\hline & $(0.000)$ & $(0.000)$ & $(0.005)$ \\
\hline \multirow[t]{2}{*}{ Post $\times$ treat $_{3}$} & $0.003 * *$ & $0.001 * *$ & 0.012 \\
\hline & $(0.000)$ & $(0.000)$ & $(0.005)$ \\
\hline \multirow[t]{2}{*}{ Post $\times$ treat $_{4}$} & 0.000 & 0.000 & 0.000 \\
\hline & $(0.000)$ & $(0.000)$ & $(0.000)$ \\
\hline \multirow[t]{2}{*}{ Sales growth } & 0.005 & $0.016^{* * *}$ & 0.152 \\
\hline & $(0.001)$ & $(0.000)$ & $(0.053)$ \\
\hline \multirow[t]{2}{*}{ Firm size } & 0.004 & $0.014 *$ & $-0.559 *$ \\
\hline & $(0.001)$ & $(0.002)$ & $(0.083)$ \\
\hline \multirow[t]{2}{*}{ Firm age } & $-0.011^{*}$ & -0.017 & -0.093 \\
\hline & $(0.001)$ & $(0.003)$ & $(0.023)$ \\
\hline \multirow[t]{2}{*}{ Constant } & $1.036 * *$ & -0.040 & $0.213 * * *$ \\
\hline & $(0.072)$ & $(0.027)$ & $(0.008)$ \\
\hline Time fixed effect & Yes & Yes & Yes \\
\hline Industry fixed effect & Yes & Yes & Yes \\
\hline Observations & 21,717 & 21,713 & 21,125 \\
\hline$R$-squared & 0.118 & 0.050 & 0.178 \\
\hline
\end{tabular}

Robust standard errors in parentheses

$* * * p<0.01 ; * * p<0.05 ; * p<0.1$

performance, and it is significant for ROE, but not for ROA and Tobin's Q. Firm size shows a consistent role in improving firm performance, and it is positive and significant at the $1 \%$ level.

Due to the adjustment time cost of firm production activities, the effect of fiscal policy implementation might have certain lagged characteristics. In this section, we estimate the dynamic effects caused by fiscal policy. In Table 3, we further explore the dynamic effects with three lagged periods, and our estimations show that the coefficients of the interaction terms are all positive and significant with the first and second lagged periods. The dynamic effects of the third lagged period are insignificant, illustrating that the low-energy-intensive fiscal support 


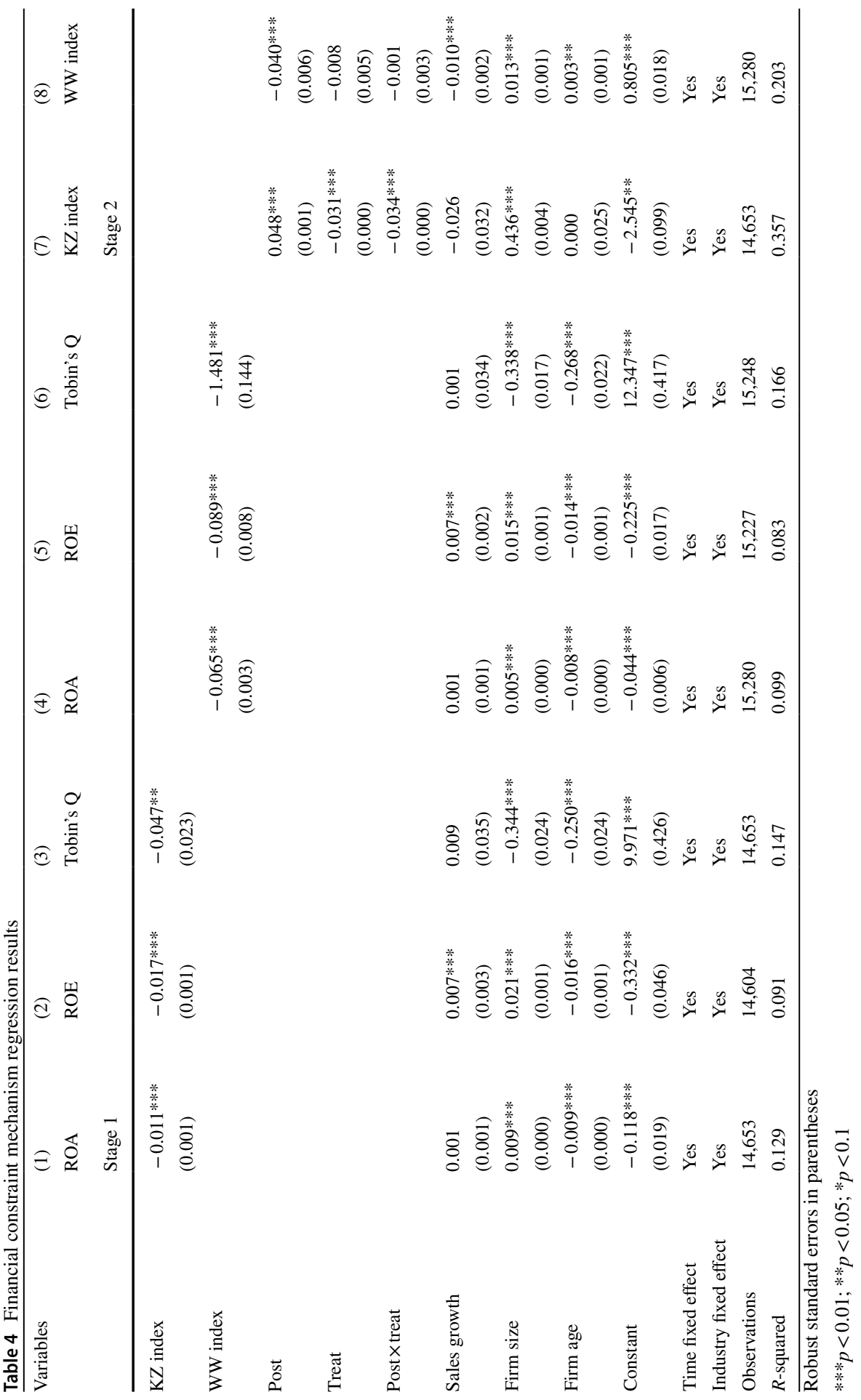


policy does improve firm performance, but the low-energy-intensive fiscal support policy effects are weakened in dynamic periods.

\subsection{Financial constraints, financial intermediation and financial management mechanisms}

We investigate the mechanism by which firm performance is improved by the lowenergy-intensive fiscal support policy through alleviation of financial constraints. To address this issue, we use a two-stage regression strategy. In stage 1, we explore the relationship between financial constraints and firm performance following Eq. (2). According to the estimation results in State 1 of Table 4, the coefficients of the KW index and WW index are significant and negative, indicating that financial constraints generally restrict firm performance. Then, we further investigate the impact of low-energy-intensive fiscal support on financial constraints in stage 2, and the coefficients of the interactor Post*Treat are negative and significant at a $1 \%$ level. In other words, green tax subsidized firms suffer less from financial constraints, resulting in improved firm performance.

The estimation results discussed above show that low-energy-intensive fiscal support policy can alleviate financial constraints, resulting in improved low-energyintensive firm performance. Therefore, it is interesting to explore which kinds of financial intermediation reduce financial constraints and contribute to firm performance. Table 5 presents the impact of financial intermediation on firm performance. We find positive joint effects of current ratio, liquidity and cash flow on firm performance for low-energy-intensive firms. Our findings show that internal financial resources are improved by tax savings (Edwards et al. 2016). In other words, our results further uncover how financial constraints are alleviated by different dimensions of financial intermediation when firms are supported by the low-energy-intensive fiscal support policy.

Further, firm performance is significantly affected by financial management, such as financial costs and R\&D expenditures. Table 6 shows the financial management mechanisms induced by the low-energy-intensive fiscal support policy, and the estimation results are reported. According to Table 6, the coefficients in columns 1-2 of the DID are negative and significant, indicating that firm management and financial costs are reduced by subsidies. The coefficient of the interaction Post*Treat in column 3 is 0.005 , significant at the $1 \%$ level, indicating that firms are more likely to finance their $R \& D$ expenditures to improve firm performance. 


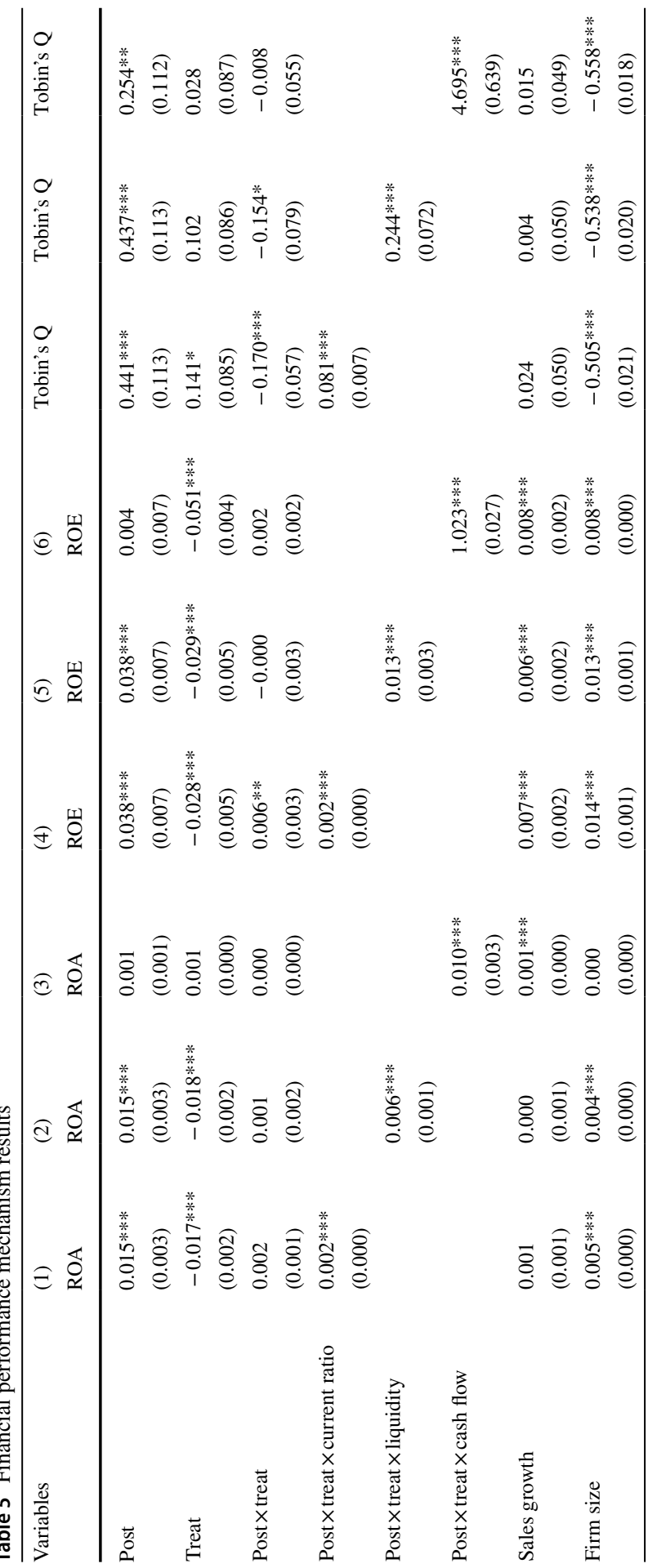




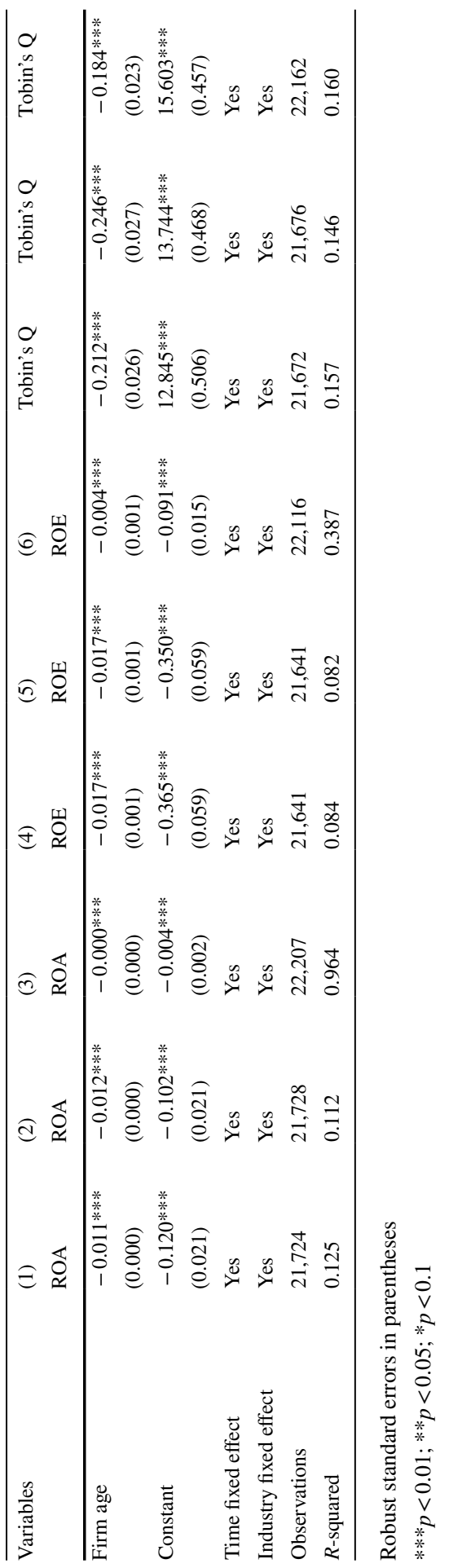


Table 6 Financial management mechanism results

\begin{tabular}{|c|c|c|c|}
\hline \multirow[t]{2}{*}{ Variables } & (1) & (2) & (3) \\
\hline & Management cost & Financial cost & R\&D expenditure \\
\hline \multirow[t]{2}{*}{ Post } & $-0.009 *$ & -0.008 & 0.000 \\
\hline & $(0.001)$ & $(0.003)$ & $(0.002)$ \\
\hline \multirow[t]{2}{*}{ Treat } & $0.024 * * *$ & -0.001 & $0.011 * * *$ \\
\hline & $(0.000)$ & $(0.000)$ & $(0.002)$ \\
\hline \multirow[t]{2}{*}{ Post $\times$ treat } & $-0.003^{* *}$ & $-0.002 *$ & $0.005 * * *$ \\
\hline & $(0.000)$ & $(0.000)$ & $(0.001)$ \\
\hline \multirow[t]{2}{*}{ Sales growth } & 0.001 & -0.002 & $0.004 * * *$ \\
\hline & $(0.001)$ & $(0.001)$ & $(0.001)$ \\
\hline \multirow[t]{2}{*}{ Firm size } & $-0.029 *$ & 0.004 & $-0.009 * * *$ \\
\hline & $(0.004)$ & $(0.002)$ & $(0.000)$ \\
\hline \multirow[t]{2}{*}{ Firm age } & 0.031 & 0.013 & $-0.006 * * *$ \\
\hline & $(0.009)$ & $(0.005)$ & $(0.001)$ \\
\hline \multirow[t]{2}{*}{ Constant } & $1.036^{* *}$ & -0.040 & $0.213 * * *$ \\
\hline & $(0.072)$ & $(0.027)$ & $(0.008)$ \\
\hline Time fixed effect & Yes & Yes & Yes \\
\hline Industry fixed effect & Yes & Yes & Yes \\
\hline Observations & 21,717 & 21,713 & 19,125 \\
\hline$R$-squared & 0.118 & 0.050 & 0.178 \\
\hline
\end{tabular}

Robust standard errors in parentheses

$* * * p<0.01 ; * * p<0.05 ; * p<0.1$

\section{Robustness tests}

To make our identification reliable, we carry out several robustness tests.

\subsection{Placebo effect test}

To identify the low-energy-intensive fiscal support policy resulting in improving firm performance, we provide a placebo effect test to re-estimate our regression results. Table 7 shows the regression results after introducing the interaction terms with one period forehead with our treatment variables. Our estimation results show that the original DID effect remains positive and significant, while the coefficients of the interaction Post*Treat-Pre are insignificant. These findings suggest that potential endogeneity problems caused by time-varying effects do not affect our baseline results, and our policy shock setting and estimation results are reliable. 
Table 7 Robustness testplacebo test

\begin{tabular}{|c|c|c|c|}
\hline Variables & $\begin{array}{l}(1) \\
\text { ROA }\end{array}$ & $\begin{array}{l}(2) \\
\text { ROE }\end{array}$ & $\begin{array}{l}(3) \\
\text { Tobin's Q }\end{array}$ \\
\hline Post & $\begin{array}{l}-0.011 * * * \\
(0.001)\end{array}$ & $\begin{array}{l}0.033 * * * \\
(0.003)\end{array}$ & $\begin{array}{l}0.444 * * * \\
(0.021)\end{array}$ \\
\hline Treat & $\begin{array}{l}-0.017 * * * \\
(0.002)\end{array}$ & $\begin{array}{l}-0.032 * * \\
(0.010)\end{array}$ & $\begin{array}{l}0.136 * * * \\
(0.015)\end{array}$ \\
\hline Post $\times$ treat & $\begin{array}{l}0.004 * * \\
(0.002)\end{array}$ & $\begin{array}{l}0.016^{*} \\
(0.008)\end{array}$ & $\begin{array}{l}0.035 * * \\
(0.010)\end{array}$ \\
\hline Post $\times$ treat-pre & $\begin{array}{l}0.002 \\
(0.001)\end{array}$ & $\begin{array}{l}-0.009 \\
(0.005)\end{array}$ & $\begin{array}{l}0.012 \\
(0.008)\end{array}$ \\
\hline Sales growth & $\begin{array}{l}0.004 * * * \\
(0.000)\end{array}$ & $\begin{array}{l}0.007 * * \\
(0.002)\end{array}$ & $\begin{array}{l}0.007 \\
(0.090)\end{array}$ \\
\hline Firm size & $\begin{array}{l}0.004 * * * \\
(0.000)\end{array}$ & $\begin{array}{l}0.013 * * * \\
(0.001)\end{array}$ & $\begin{array}{l}-0.534 * * * \\
(0.016)\end{array}$ \\
\hline Firm age & $\begin{array}{l}-0.011 * * * \\
(0.000)\end{array}$ & $\begin{array}{l}-0.017 * * * \\
(0.001)\end{array}$ & $\begin{array}{l}-0.246 * * \\
(0.099)\end{array}$ \\
\hline Constant & $\begin{array}{l}-0.060 * * * \\
(0.006)\end{array}$ & $\begin{array}{l}-0.248 * * * \\
(0.014)\end{array}$ & $\begin{array}{l}14.790 * * * \\
(0.334)\end{array}$ \\
\hline Time fixed effect & Yes & Yes & Yes \\
\hline Industry fixed effect & Yes & Yes & Yes \\
\hline Observations & 22,207 & 22,116 & 22,162 \\
\hline$R$-squared & 0.082 & 0.083 & 0.149 \\
\hline
\end{tabular}

Robust standard errors in parentheses

$* * * p<0.01 ; * * p<0.05 ; * p<0.1$

\subsection{Robustness test and COVID-19 impact checks}

To test whether our baseline regressions are reliable in the context of the COVID-19 epidemic, we carry out a robustness test by changing the interaction term Post ${ }^{*}$ Treat into Post*Treat* ${ }^{*}$ Confirmed Cases. According to the results shown in Table 8 , the coefficients of the interactions are positive and significant, indicating that lowenergy-intensive firms benefit more from the low-energy-intensive fiscal support policy, particularly in areas with severe spread of COVID-19.

\subsection{Robustness test: endogeneity problem solved by system generalized method of moments between groups}

We explore whether our baseline regressions are challenged by a potential endogeneity problem, which may be caused by omitted variables or reverse causality. We carry out a robustness test by using the generalized method of moments (GMM) method between supported and un-supported firms. According to the results presented in Table 9, the coefficients of the post-variable are positive and significant, indicating that low energy consuming firms benefit significantly from 
Table 8 Robustness test: COVID-19-confirmed cases checks

\begin{tabular}{|c|c|c|c|}
\hline \multirow[t]{2}{*}{ Variables } & (1) & (2) & (3) \\
\hline & ROA & ROE & Tobin's Q \\
\hline \multirow[t]{2}{*}{ Post } & $0.021 * * *$ & $0.020 *$ & $0.622 * * *$ \\
\hline & $(0.004)$ & $(0.011)$ & $(0.149)$ \\
\hline \multirow[t]{2}{*}{ Treat } & $-0.008 * * *$ & $-0.009 * * *$ & -0.068 \\
\hline & $(0.001)$ & $(0.003)$ & $(0.093)$ \\
\hline \multirow[t]{2}{*}{ Post $\times$ treat $\times$ confirmed cases } & $0.001 * * *$ & $0.001 *$ & $0.047 * * *$ \\
\hline & $(0.000)$ & $(0.001)$ & $(0.014)$ \\
\hline \multirow[t]{2}{*}{ Sales growth } & -0.001 & 0.004 & -0.085 \\
\hline & $(0.002)$ & $(0.003)$ & $(0.073)$ \\
\hline \multirow[t]{2}{*}{ Firm size } & $0.003 * * *$ & $0.009 * * *$ & $-0.471 * * *$ \\
\hline & $(0.000)$ & $(0.001)$ & $(0.028)$ \\
\hline \multirow[t]{2}{*}{ Firm age } & $-0.009 * * *$ & $-0.013 * * *$ & $-0.488 * * *$ \\
\hline & $(0.001)$ & $(0.002)$ & $(0.043)$ \\
\hline \multirow[t]{2}{*}{ Confirmed cases } & $-0.002 * * *$ & $-0.003 * * *$ & 0.023 \\
\hline & $(0.000)$ & $(0.001)$ & $(0.023)$ \\
\hline \multirow[t]{2}{*}{ Constant } & $-0.025^{* *}$ & $-0.081 * *$ & $13.080 * * *$ \\
\hline & $(0.011)$ & $(0.032)$ & $(0.667)$ \\
\hline Time fixed effect & Yes & Yes & Yes \\
\hline Industry fixed effect & Yes & Yes & Yes \\
\hline Observations & 9495 & 9417 & 9473 \\
\hline$R$-squared & 0.167 & 0.117 & 0.157 \\
\hline
\end{tabular}

Robust standard errors in parentheses

$* * * p<0.01 ; * * p<0.05 ; * p<0.1$

the low-energy-intensive fiscal support policy. Coefficients of the post-variable are insignificant, illustrating that high-energy-consuming firms do not benefit from the low-energy-intensive fiscal support policy, consistent with our fundamental findings.

\section{Conclusions and policy recommendations}

In the wake of the COVID-19 pandemic, with easing restrictions and re-opening economies, governments are beginning to unveil their economic recovery plans. However, there is a lack of motivation to strengthen the green agenda in recovery plans. This is because the recovery outlook seems to follow the "growth first and green it when possible" approach of existing development plans. How can firms survive and pursue green development given the shocks of the COVID-19 pandemic? This paper draws on the impact of fiscal policy on recovering firm performance. 
Table 9 Robustness test-endogeneity problem solved by system GMM between groups

\begin{tabular}{|c|c|c|c|c|c|c|}
\hline Variables & $\begin{array}{l}(1) \\
\text { ROA }\end{array}$ & $\begin{array}{l}(2) \\
\text { ROA }\end{array}$ & $\begin{array}{l}(3) \\
\text { ROE }\end{array}$ & $\begin{array}{l}(4) \\
\text { ROE }\end{array}$ & $\begin{array}{l}\text { (5) } \\
\text { Tobin's Q }\end{array}$ & $\begin{array}{l}(6) \\
\text { Tobin's Q }\end{array}$ \\
\hline L.ROA & $\begin{array}{l}0.625 * * * \\
(0.031)\end{array}$ & $\begin{array}{l}0.580 * * * \\
(0.026)\end{array}$ & & & & \\
\hline L.ROE & & & $\begin{array}{l}0.559 * * * \\
(0.068)\end{array}$ & $\begin{array}{l}0.270 * * * \\
(0.029)\end{array}$ & & \\
\hline L.Tobin's Q & & & & & $\begin{array}{l}0.909 * * * \\
(0.040)\end{array}$ & $\begin{array}{l}0.915 * * * \\
(0.042)\end{array}$ \\
\hline Post & $\begin{array}{l}0.003 * * \\
(0.001)\end{array}$ & $\begin{array}{l}-0.011 \\
(0.007)\end{array}$ & $\begin{array}{l}0.008 * * * \\
(0.003)\end{array}$ & $\begin{array}{l}0.002 \\
(0.003)\end{array}$ & $\begin{array}{l}0.081 * * * \\
(0.022)\end{array}$ & $\begin{array}{l}0.046 \\
(0.029)\end{array}$ \\
\hline Sales growth & $\begin{array}{l}0.012 * * * \\
(0.001)\end{array}$ & $\begin{array}{l}0.006 * * * \\
(0.002)\end{array}$ & $\begin{array}{l}0.023 * * * \\
(0.003)\end{array}$ & $\begin{array}{l}0.017 * * * \\
(0.001)\end{array}$ & $\begin{array}{l}0.071 * * * \\
(0.010)\end{array}$ & $\begin{array}{l}0.048 * * * \\
(0.008)\end{array}$ \\
\hline Firm size & $\begin{array}{l}0.001 * * \\
(0.000)\end{array}$ & $\begin{array}{l}0.000 \\
(0.000)\end{array}$ & $\begin{array}{l}0.004 * * * \\
(0.001)\end{array}$ & $\begin{array}{l}0.007 * * * \\
(0.001)\end{array}$ & $\begin{array}{l}-0.035^{* *} \\
(0.018)\end{array}$ & $\begin{array}{l}-0.043^{* *} \\
(0.021)\end{array}$ \\
\hline Firm age & $\begin{array}{l}-0.004^{* * * *} \\
(0.001)\end{array}$ & $\begin{array}{l}-0.004 * * * \\
(0.001)\end{array}$ & $\begin{array}{l}-0.008 * * * \\
(0.002)\end{array}$ & $\begin{array}{l}-0.011 * * * \\
(0.001)\end{array}$ & $\begin{array}{l}-0.047^{* * *} \\
(0.017)\end{array}$ & $\begin{array}{l}-0.033^{* *} \\
(0.015)\end{array}$ \\
\hline Constant & $\begin{array}{l}-0.014 \\
(0.009)\end{array}$ & $\begin{array}{l}0.000 \\
(0.000)\end{array}$ & $\begin{array}{l}-0.069 * * * \\
(0.027)\end{array}$ & $\begin{array}{l}-0.118^{* * *} \\
(0.018)\end{array}$ & $\begin{array}{l}0.926 * \\
(0.479)\end{array}$ & $\begin{array}{l}1.161 * * \\
(0.549)\end{array}$ \\
\hline $\begin{array}{l}\text { Time fixed } \\
\text { effect }\end{array}$ & Yes & Yes & Yes & Yes & Yes & Yes \\
\hline $\begin{array}{l}\text { Industry } \\
\text { fixed effect }\end{array}$ & Yes & Yes & Yes & Yes & Yes & Yes \\
\hline $\begin{array}{l}\text { Observa- } \\
\text { tions }\end{array}$ & 5712 & 12,844 & 5681 & 12,844 & 5695 & 12,876 \\
\hline $\mathrm{AR}(2)$ & 0.267 & 0.147 & 0.197 & 0.218 & 0.339 & 0.298 \\
\hline $\begin{array}{l}\text { Hansen } J \\
\text { test }\end{array}$ & 0.844 & 0.181 & 0.295 & 0.587 & 0.195 & 0.277 \\
\hline
\end{tabular}

Robust standard errors in parentheses

$* * * p<0.01 ; * * p<0.05 ; * p<0.1$

To cope with the aims of green production and economic recovery, the Chinese government has implemented a green incentive tax as a trial to reduce energy costs in low-energy-intensive firms. To estimate the impact of the green incentive tax on firm performance, controlling for time-varying and time-invariant industry controls and DID estimations are used to measure the effects of the policy. We find strong evidence that the low-energy-intensive fiscal support policy can significantly improve low-energy-intensive firms' performance over that of high-energy-intensive firms, including ROA, ROE and Tobin's Q. Our findings indicate that a well-designed fiscal policy can not only help firms overcome the uncertainty caused by COVID-19, but also contribute to green recovery and green-oriented upgrading. In addition, regarding the underlying mechanisms, our estimation results show that the low-energy-intensive fiscal support policy works 
by alleviating financial constraints to improve firm performance. This indicates that financial development is a main driver of green recovery in firms that benefit from the positive effect of fiscal policy. Further, our empirical findings indicate that supportive tax policy can increase current ratio, liquidity and cash flow, resulting in improved firm financial resources. Finally, tax support policy reduces management and financial costs, thus improving firm performance as well.

Accordingly, we draw several policy implications both for government regulators and corporate managers. First, a well-designed fiscal policy is an efficient tool for government to address market failure and economic uncertainty. Second, a well-designed fiscal tool can help upgrade industry from being energy-intensive and move toward greater use of renewable energy. Our findings indicate that lowenergy-intensive firms can benefit from tax reduction policy, helping such firms to survive and overcome the economic uncertainty caused by COVID-19 and to further upgrade operations. Third, corporate managers should pay more attention to green energy inputs and green production, as green recovery can help firms better survive in competitive markets.

\section{References}

Alm J, Liu Y, Zhang K (2019) Financial constraints and firm tax evasion. Int Tax Public Finance 26:71-102

Bayar O, Huseynov F, Sardarli S (2018) Corporate governance, tax avoidance, and financial constraints. Financ Manag 47(3):651-677

Bloom N, Griffith R, Reenen JV (2002) Do R\&D tax credits work? Evidence from a panel of countries 1979-1997. J Public Econ 85:1-31

Bu D, Zhang C, Wang X (2017) Purposes of government subsidy and firm performance. China J Account Stud 5(1):100-122

Dabla-Norris E, Misch F, Cleary D, Khwaja M (2019) The quality of tax administration and firm performance: evidence from developing countries. Int Tax Public Finance 27:1-38

Dever P (2010) Reforming subsidies in the federal budget. Polit Policy 36(5):854-878

Edwards AS, Schwab CM, Shevlin T (2016) Financial constraints and cash tax savings. Account Rev 91(3):859-881

Firth M, Fung P, Rui OM (2006) Firm performance, governance structure, and top management turnover in a transitional economy. J Manag Stud 43(6):1289-1330

Giombini G, Teobaldelli D, Schneider F (2018) Interaction effect of tax evasion and legal system inefficiency on firms' financial constraints. Int Rev Econ Financ 55:1-20

Howell A (2016) Firm R\&D, innovation and easing financial constraints in China: Does corporate tax reform matter? Res Policy 45(10):1996-2007

Kim DH, Wu YC, Lin SC (2021) Carbon dioxide emissions, financial development and political institutions. Econ Change Restruct. https://doi.org/10.1007/s10644-021-09331-x

Klassen KJ, Pittman JA, Reed MP, Fortin S (2004) A cross-national comparison of R\&D expenditure decisions: tax incentives and financial constraints. Contemp Account Res 21(3):639-680

Nishimura J, Okamuro H (2011) Subsidy and networking: the effects of direct and indirect support programs of the cluster policy. Res Policy 40(5):714-727

Sachs JD, Schmidt-Traub G, Mazzucato M, Messner D, Nakicenovic N, Rockström J (2019) Six transformations to achieve the sustainable development goals. Nat Sustain 2(9):805-814

Sartzetakis ES (2020) Green bonds as an instrument to finance low carbon transition. Econ Change Restruct. https://doi.org/10.1007/s10644-020-09266-9

Shaikh I (2021) Impact of COVID-19 pandemic on the energy markets. Econ Change Restruct. https:// doi.org/10.1007/s10644-021-09320-0 
Taghizadeh-Hesary F, Yoshino N (2019) The way to induce private participation in green finance and investment. Financ Res Lett 31:98-103

Tang QQ, Luo DL (2007) Empirical analysis on government subsidy motivation and its effects. J Financ Res 6:149-163

Wu W, Wu C, Zhou C, Wu J (2012) Political connections, tax benefits and firm performance: evidence from China. J Account Public Policy 31:277-300

Whited TM, Wu G (2006) Financial constraints risk. Rev Financ Stud 2:531-559

Yoshino N, Taghizadeh-Hesary F, Otsuka M (2021) Covid-19 and optimal portfolio selection for investment in sustainable development goals. Finance Res Lett 38:101695

Zakari A, Adedoyin FF, Taghizadeh-Hesary F, Pazouki A (2021) Environmental treaties' impact on the environment in resource-rich and non-resource-rich countries. Environ Sci Pollut Res 28(6):33108-33119

Zhang D (2019) Can export tax rebate alleviate financial constraint to increase firm productivity? Evidence from China. Int Rev Econ Financ 64:529-540

Zhang D (2021) Is export tax rebate a quality signal to determine firms' capital structure? A financial intermediation perspective. Res Int Bus Finance 55:101317

Zhang D, Vigne SA (2021a) How does innovation efficiency contribute to green productivity? A financial constraint perspective. J Clean Prod 280:124000

Zhang D, Vigne SA (2021b) The causal effect on firm performance of China's financing-pollution emission reduction policy: firm-level evidence. J Environ Manag 279:111609

Zhang D, Zhuge L, Freeman RB (2020) Firm dynamics of hi-tech start-ups: Does innovation matter? China Econ Rev 59:101370

Zhang D, Mohsin M, Rasheed AK, Chang Y, Taghizadeh-Hesarye F (2021) Public spending and green economic growth in BRI region: mediating role of green finance. Energy Policy 153:112256

Publisher's Note Springer Nature remains neutral with regard to jurisdictional claims in published maps and institutional affiliations. 